\title{
Order of Modifiers in Kîtharaka Determiner Phrase
}

\author{
Patrick Njue Kanampiu*, Peter Kinyua Muriungi \\ Kenya \\ *Corresponding Author: Patrick Njue Kanampiu, Kenya

\begin{abstract}
This paper argues that Kîtharaka has a neutrall order of modifiers within its determiner phrase. Apart from this neutral order, other orders are possible depending on the modifier upon which focus is placed. Ordering of modifiers in Kîtharaka is achieved through movement of NP to the specifier position of $D P$. Elements like the demonstrative and the quantifier also undergo head-to-head movement between $D$ and $N$.
\end{abstract}

\section{INTRODUCTION}

Kîitharaka is a Bantu language basically spoken by the Atharaka people in Tharaka South and North Sub-counties in Tharaka Nithi County of Kenya. It is also spoken by a section of people who live across Tana river in Kitui and part of Mwingi county. In the classification system of Guthrie (1967) the language is classified as part of zone E group thus coded E54. It belongs to the Bantu sub-group of the Niger-Kordofanian language group. Bantu languages are part of the largest African language family: Niger-Congo.

In this paper, we have found it necessary to first review some background information related to order of modifiers in general and also in Bantu. We have then analysed the typology of Kît tharaka DP modification by looking at how the positions occupied by various elements that constitute the DP. The information has been presented stepwise from addition of one modifier to the next until all possible modifiers have been covered. We have also employed diagrammatic illustrations to demonstrate the principle of movement that Kîtharaka employs to drive its neutral order from the underlying structure proposed by Cinque (2005). Lastly, we have taken a close look at order of modifiers in other Bantu languages so as to put Kîitharaka into the right typological context vis-à-vis other Bantu languages.

\section{BACKGROUND ON WORD ORDER IN THE DP}

Generally, Cinque (2005) observes that the languages of the world underlie the order; DET> NUM> ADJ > N. He posits that languages which exhibit a different order derive their ordering from the underlying structure through movement of elements between $\mathrm{D}^{1}$ and N. Cinque's structure becomes useful, therefore, as a typological framework across languages of the world.

Important to this paper, also, is the observations by some linguists that until relatively recent years, there wasn't much detailed studies on the order of elements in the Bantu languages. Linguists had focused on concord within the noun phrase and overlooked the grammar of word ordering (cf. Nurse \& Philippson, 2003; Rugemalira, 2007; Ngonyani, 2003; Mchombo, 2005). The situation has, however, changed in recent years. Lusekelo (2009) observes that some Bantuists have since given the field of word order in the DP some more attention. This shows that the subject of modifier ordering in the DP across many Bantu languages is still under researched.

On the order of elements within the DP, Van de Velde (2005) observes that Bantu languages, in general, exhibit head-before-dependent (HD) order, with exception of some languages like Nen (A44) which exhibits a peculiar order, as will later be illustrated. Other exceptions witnessed is in regard to optional pre-nominal positioning of some elements like the demonstrative and other words like 'other' (Ibid) and the distributive ${ }^{2}$ kila 'each/every' (Rugemalira, 2007; Polome 1967; Ashton, 1944).

\footnotetext{
${ }^{1} \mathrm{D}$ here stands for determiner, realized as DET in the given underlying structure

${ }^{2}$ The term is also referred to as invariable by Ashton (1944). It is used to refer to words which stand for 'each/every' in English.
} 
Additionally, Van de Velde (2007) observes that languages which exhibit basic word order allow to different extents pragmatically motivated deviation from the basic order. He, however, observes that Bantu languages are exceptional because they exhibit a lot of freedom in mutual ordering of postmodifiers. ${ }^{3}$ This freedom should not, however, be construed to mean there are no restrictions on the word order in the given languages. Rugemalira (2007) summarizes general order of modifiers in Bantu as follows:

\begin{tabular}{|l|l|l|l|l|l|l|l|l|}
\hline 01 & 0 & \multicolumn{1}{|l|}{ l } & \multicolumn{2}{l|}{} & 3 \\
\hline Pred. & N & Det. & \multicolumn{3}{l|}{ Modifiers } & Post. Mod \\
\hline & & & a & b & c & d & e & \\
\hline Det. & Noun & Poss. & & & & & & \\
\hline Distr. & & Det. & Num. & Ord. Ass. & Qua. & Adj. & Rel. Clause & Inter. \\
\hline
\end{tabular}

Source: Rugemalira (2007:147)

Rugemalira's analysis to a greater extent captures the prevailing typological characteristics across many Bantu languages. However, as we will demonstrate later using Kîtharaka data, the framework may not be used as a blueprint to explain order of modifiers across all Bantu languages because of idiosyncratic differences of the Bantu languages. One such idiosyncratic feature in Kîitharaka is the existence of two forms of associative construction in the language; the ordinal association and the possessive association. Using Kîtharaka we will show that these forms of associative construction can actually co-occur in the DP and when they do, they take different positions in the modifier spectrum. This has not been accounted for in Rugemalira's (ibid) framework. The other issue that has been queried is the pre-determiner position, which has been shown not to exist in a number of Bantu languages (cf. Lusekelo, 2009; Van de Velde, 2007).

The existing literature, therefore, proves that there is a variation of how individual Bantu languages order elements within the DP, making it necessary to study individual Bantu Languages, Kîtharaka included.

\section{Kî̂THARAKA AND THE UNDERLYING STRUCTURE}

The order of various elements in a determiner phrase may be similar or differ from one language to another, according to idiosyncratic features of various languages of the world (Sulemana, 2012). Furthermore, borrowing from Cinque (2005), we observe that Kîtharaka underlies the order DEMNUM-ADJ-N. Notably, this underlying structure has a pre-nominal order of modifiers. To achieve its post-nominal order of modifiers, Kîtharaka NP moves from the underlying position to the left-most position in the DP. Using a DP structure with the noun only, we can illustrate the NP movement as follows:

(1)

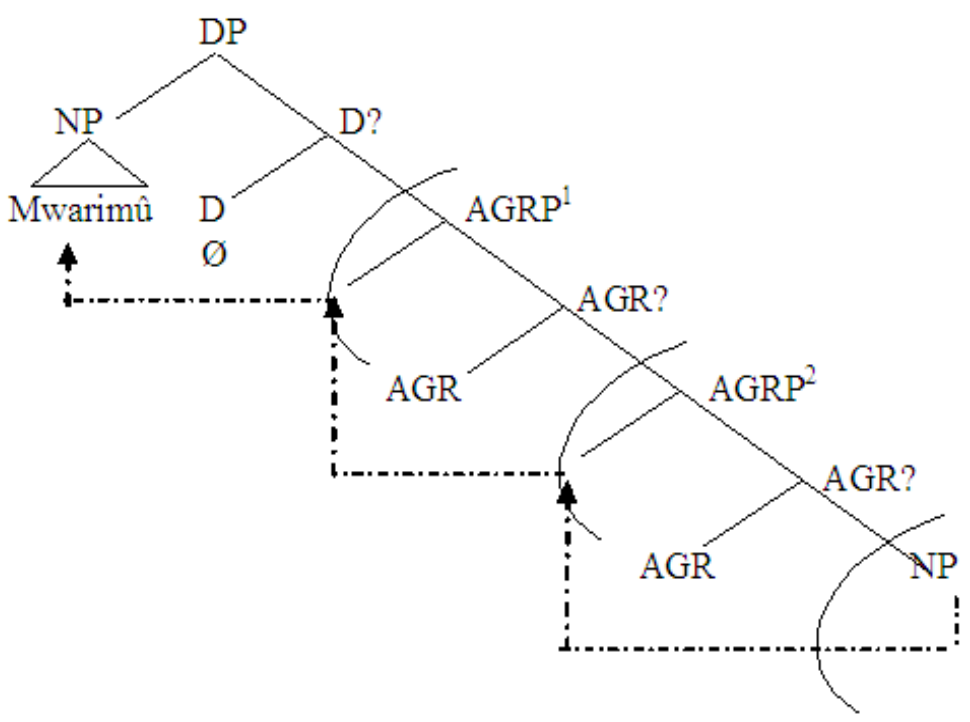

\footnotetext{
${ }^{3}$ Van de Velde (2007) further clarifies that this freedom should not be traken to mean that there are no restrictions on the modifier ordering.
} 
Structure (1) illustrates the NP Mwarimû (teacher) moving from the underlying position through specifier position of agreement phrases to the specifier position of DP to achieve the correct word order in Kîitharaka.

\section{Kî̂THARAKa ORder OF MODIFIERS}

Kîitharaka DP structure may range from a minimum of one element, to a string of several elements. When the DP is made of a demonstrative and the noun, normally, the noun precedes the demonstrative, achieving the order $N>$ Dem. In this, Kîtharaka agrees with many other Bantu languages like Kikuyu (E51), Ruguru (G35), Nyakyusa (M31) and many others. This is illustrated in example 2:

$$
\begin{aligned}
& \text { (2) a) Mû-thaka û-ûra } \\
& \text { 14-Young man 1-that } \\
& \text { 'That young man' } \\
& \begin{array}{l}
\text { b) Kî-banga kî-îra } \\
\text { 7-Panga 7- that } \\
\text { 'That panga' }
\end{array}
\end{aligned}
$$

Other structures are also possible. For instance, it is possible for a demonstrative to precede the noun in the context of creative use of language to achieve a dramatic effect through emphasis. In this case, the demonstrative is given focus as illustrated in (3):

$$
\begin{gathered}
\text { (3) Ka-ara ka-ana }{ }^{5} \\
\text { 12-that 12-child } \\
\text { 'That child' }
\end{gathered}
$$

There are two possibilities responsible for achievement of structure (3). Either the noun abstains from moving from the underlying position, or the demonstrative pied-pies past the noun. ${ }^{6}$ We however, need to get it clear here that the demonstrative coming before the noun is not typical, but for the reason we have given earlier. Van de Velde (2007) cites other languages like Bankon (A42), Nkore (J13), Bemba (M42) and many more others that allow the demonstrative to precede the noun to achieve emphasis.

In a DP with the noun, demonstrative and possessive the neutral order is $N>D E M>P O S S$. This is illustrated as follows:

$\begin{array}{ll}\text { (4) a) Ka-ana ka-ara } & \text { ga-kwa } \\ \text { 12-Child 12-that } & \text { 12-mine } \\ \text { 'That child of mine' } & \\ \text { b) Mw-arimû û-ûra } & \text { gw-etû } \\ \text { 1-teacher 1-that } & \text { 1-ours }\end{array}$

Just like in the case of the demonstrative, it is possible to give focus to the possessive, so that it precedes the noun in the structure. Similarly, the resultant structure is not also typical, but acceptable incases of emphasis.

The quantifier typically follows the possessive, to achieve the order $N>D E M>P O S S>Q U A$, as exemplified in 5:

(5) a) A-ana

$$
\begin{array}{lrrr}
\text { A-ana } & \text { ba-ara } & \text { ba-akwa } & \text { ba-thatû } \\
\text { 2-children } & \text { 2-those } & \text { 2-mine } & \text { 2-three }
\end{array}
$$

\footnotetext{
${ }_{5}^{4}$ A numeral on the gloss shows the noun class of the respective class markers.

${ }^{5}$ It should be noted, however, that the structure is not typical and only happens when the speaker focuses on the demonstrative, giving it prominence over the noun.

${ }^{6}$ The rationale of demonstrative movement is borrowed from Giusti (1997).
} 
'Those three children of mine'

$\begin{array}{llrr}\text { b) N-kaarî } & \text { ci-ira } & \text { ci-akwa } & \text { ci-îrî } \\ \text { 10-car } & \text { 10-those } & \text { 10-mine } & \text { 10-two }\end{array}$

'those two cars of mine'

Exceptionally, a distributive quantifier takes a pre-nominal position, as illustrated in structure 6:

(6) Kîra mûrutwa

Each/every student

'Each/every student'

The quantifier is a special word class because it houses different sub-classes such as definite and indefinite quantifiers, ordinal and cardinal numbers. Indeed the complexity associated with Bantu quantifiers is well captured by Zerbian \& Krifka (2008) who observe that Bantu languages manifest a range of nominal modification with quantitative interpretation. In some structures, more than one sub-category may be present. It's important, therefore, to pay some more attention the syntax of quantifiers. Being a functional category, the quantifier projects its own phrase between D and N. In a structure with a possessive and a quantifier for instance, the possessive takes the position of D. In this case, it serves as a determiner. The quantifier phrase serves as the complement of the determiner phrase. The noun specifies the entire DP, as illustrated in structure 7:

(7) a) A-ntû ba-akwa ba-onthe
2-people 2-my
'All my people'

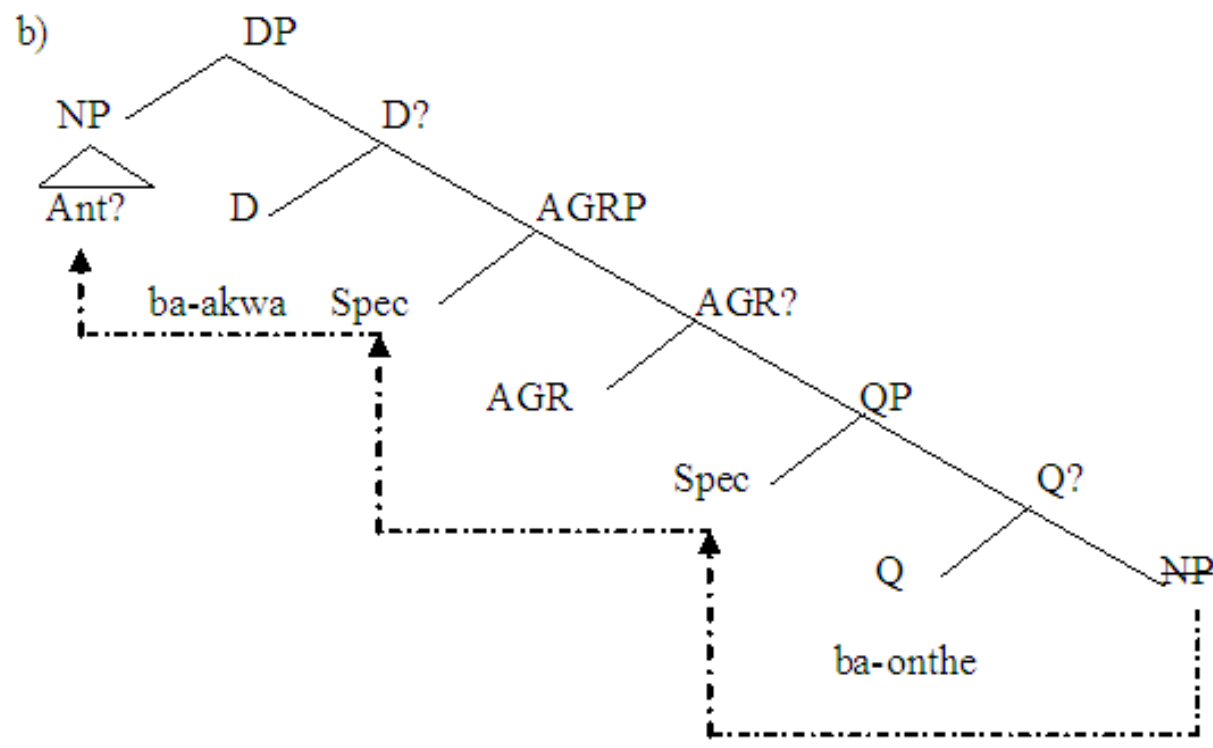

Notably, NP in the above structure undergoes movement. It moves from the underlying position, through the specifier positions of QP, AGRP and occupies the specifier position of DP to achieve the correct order of modifiers in Kîtharaka, thus, antû bakwa bonthe. This movement is motivated by the need to check agreement features. Shlonsky (1991), while analyzing floating quantifiers in Hebrew language, observes that the DP (NP in our structure), initially generated as a complement of the quantifier, is moved leftwards to the specifier position of QP, then to a position higher up in the structure, leaving behind the quantifier.

It is worth noting, however, that quantifiers can serve two syntactic roles: as modifiers or as heads of noun phrases (Coene and D'hulst, 2002). For the quantifier to serve as the head of the NP (DP in this paper), it must not be preceded by any other modifier. On the other hand, a quantifier functioning as a modifier is preceded by another/other modifiers in the structure.

We can, therefore, observe that in Kîtharaka DP, a quantifier that is not preceded by any other modifier does not project a quantifier phrase. It rather takes the position of D in the structure, therefore, functioning as the head of the phrase. Such a structure is illustrated in illustration 8: 
$(8)$

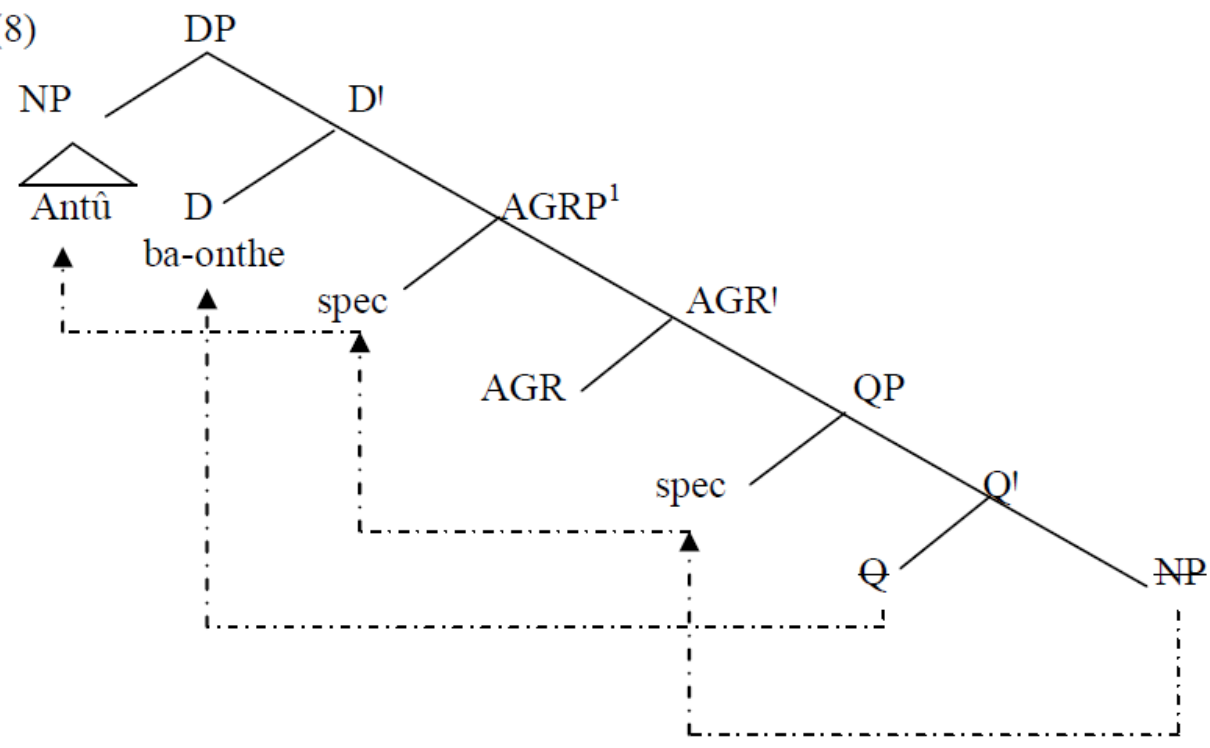

In Structure 7, the quantifier baonthe (which is pronounced as bonthe) is generated at Q. Since D, a strong head position is unoccupied; it moves through the principle of greed and occupies the vacant position. The noun also moves through the specifier positions of various functional projections and lands at the specifier position of DP where it checks number feature.

We have since, observed that quantifiers exist in terms of cardinal numbers, ordinal numbers and indefinite quantifiers like the one we have illustrated in Structure (7). Additionally, in Kîtharaka, it is possible to have a structure with the three categories of quantifiers. Such a structure is illustrated in 9:

(8) a) A-ntû ba-ara ba-akwa ba-onthe ba-thatû ba mbere 2-People 2-those 2-mine 2-all 2-three 2-of first 'All those first three people of mine'

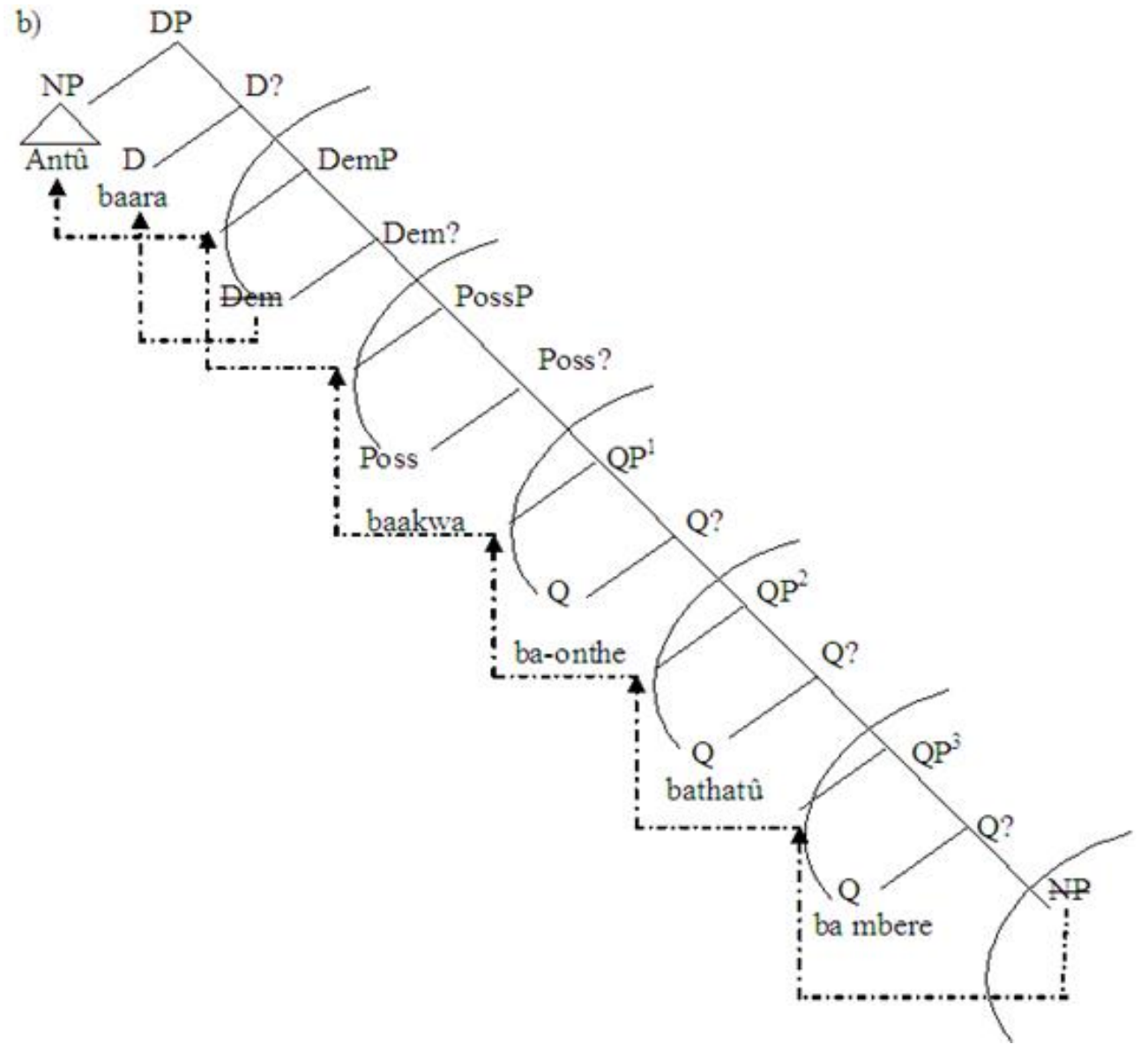


Structure 9(b) illustrates how a series of Kîitharaka quantifiers are projected within the DP. The indefinite quantifier baonthe (all) is projected in QP1, higher in the structure than the others. It is followed by the cardinal number bathat $\hat{u}$ (three), projected in QP2 and lastly, the ordinal number $b a$ mbere (first) in QP3 which is another form of quantifier.

It is worth noting that in between each of the functional projections in Structure 9(b), there is an agreement phrase that licenses agreement as indicated in the sentential structure in 9(a). We have avoided projecting them herein because the concept has already been demonstrated in structure 8 .

As with the modifiers we have already looked at, the quantifier can, for purposes of emphasis, appear before the possessive. Let us study the following examples:
a) $A-n t \hat{u}$
$b a-k w a$
ba-that
ba- kû- buutwa.
10- people
10-mine
10-three
10-Inf- sack.

'My three men have been sacked.'

$\begin{array}{llll}\text { b) } A \text {-nt } & \text { ba-that } & \text { ba-akwa } & \text { ba- kû- buutwa } \\ \text { 10-people } & \text { 10-three } & 10 \text {-mine } & \text { 10-Inf- sack }\end{array}$

'Three of my men have been sacked.'

In the DP structure in 10 (a), the quantifier bathatû appears as the third element. In (b), however, it appears between the possessive baakwa and the noun antû.

The ordinal typically follows the quantifier, achieving the order, $N>D E M>P O S S>Q U A>O R D . A S S^{7}$. This is illustrated as follows:

$\begin{array}{llllll}\text { a) A-ntû } & \text { ba-ara } & \text { ba-kwa } & \text { ba-îrî } & b a & \text { mbere } \\ \text { 2-People } & \text { 2-those } & \text { 2-mine } & \text { 2-two } & \text { 2-of first }\end{array}$

'Those first two people of mine'

$\begin{array}{llllll}\text { b) Ny-omba } & \text { i-ira } & \text { ci-akwa } & \text { ci-îrî } & \text { ci-a } & \text { mbere } \\ \text { 10-houses } & \text { 10-those } & \text { 10-mine } & \text { 10-two } & \text { 10-of } & \text { fisrt }\end{array}$

'Those first two houses of mine.'

Structure (11), illustrates the neutral positioning of the ordinal association after the quantifier. At this point the modifier order in Kîtharaka differs from the findings of Rugemarila (2007) on general ordering in Bantu, where the ordinal association precedes the quantifier. However, it is possible to move the ordinal leftwards past the possessive for purposes of emphasis. Let us examine the following data:

(11)

$\begin{array}{llllll}\text { a) A-ntû } & \text { ba-ara } & \text { ba-kwa } & \text { ba } & \text { mbere } & \text { ba-îrî } \\ \text { 2-people } & \text { 2-those } & \text { 2-mine } & \text { 2-of } & \text { first } & \text { 2-two }\end{array}$

'Those first two people of mine'

$\begin{array}{llllll}\text { b) A-ntû } & \text { ba-ara } & b a & \text { mbere } & \text { ba-akwa } & \text { ba-îrî } \\ \text { 2-people } & \text { 2-those } & \text { 2-of } & \text { first } & \text { 2-me } & \text { 2-two }\end{array}$

'Those first two people of mine.'

The structures in illustration (12) show other possible positions of the ordinal ba mbere other than the neutral one. In (a), the ordinal, having received focus, has moved leftwards past the quantifier baîri. In (b), the same ordinal moves past the quantifier and the possessive baakwa. At this position, it is more emphatic than both the possessive and the quantifier. We, however, need to underscore that the ordinal association preceding the quantifier is not natural for Kîtharaka.

\footnotetext{
${ }^{7}$ The Kîitharaka ordinal is in form of associative construction, thus, herein treated as ordinal association. 
When an adjective is introduced, it typically occupies the position after the ordinal. The resultant order is, thus, $N>D E M>P O S S>Q U A>O R D$.ASS $>A D J$. If the ordinal is absent, the adjective follows the quantifier, as illustrated in example 13:

\begin{tabular}{|c|c|c|c|}
\hline \multicolumn{2}{|c|}{ a) Ka-ana } & ka-ara & ga-akwa \\
\hline 12-child & 12-that & 12-me & 12 -small \\
\hline \multicolumn{4}{|c|}{ 'that small child of mine' } \\
\hline kaarî & 1-îra & ya-akwa & n-tuune \\
\hline Car & 9-that & 9-me & 9-red \\
\hline
\end{tabular}

There are two ways of handling adjectives in the DP structure. They can be treated as being hosted by various functional projections between D and N. This argument is supported by Cinque (1990, 1993) and Crisma (1990, 1993). On the other hand, Bernstern (1993) and Radford (2004) treat adjectives as phrasal adjuncts adjoined to NP. When treated this way, they do not interfere with movements within the DP, especially overt noun raising, a parameter common in languages that exhibit post nominal adjectives (Rizzi, 1990). Kîttharaka exhibits post-nominal adjectives, thus occasioning NP movement. We, therefore, treat adjectives as phrasal adjuncts so as not to interfere with NP movement. Illustration 14 shows the structure of a DP with a single adjective:

$$
\begin{aligned}
& \text { a) M-warî } \text { û-mû-thongi } \\
& \text { 1-Girl f- 1-beautiful } \\
& \text { 'a beautiful girl' }
\end{aligned}
$$

b)

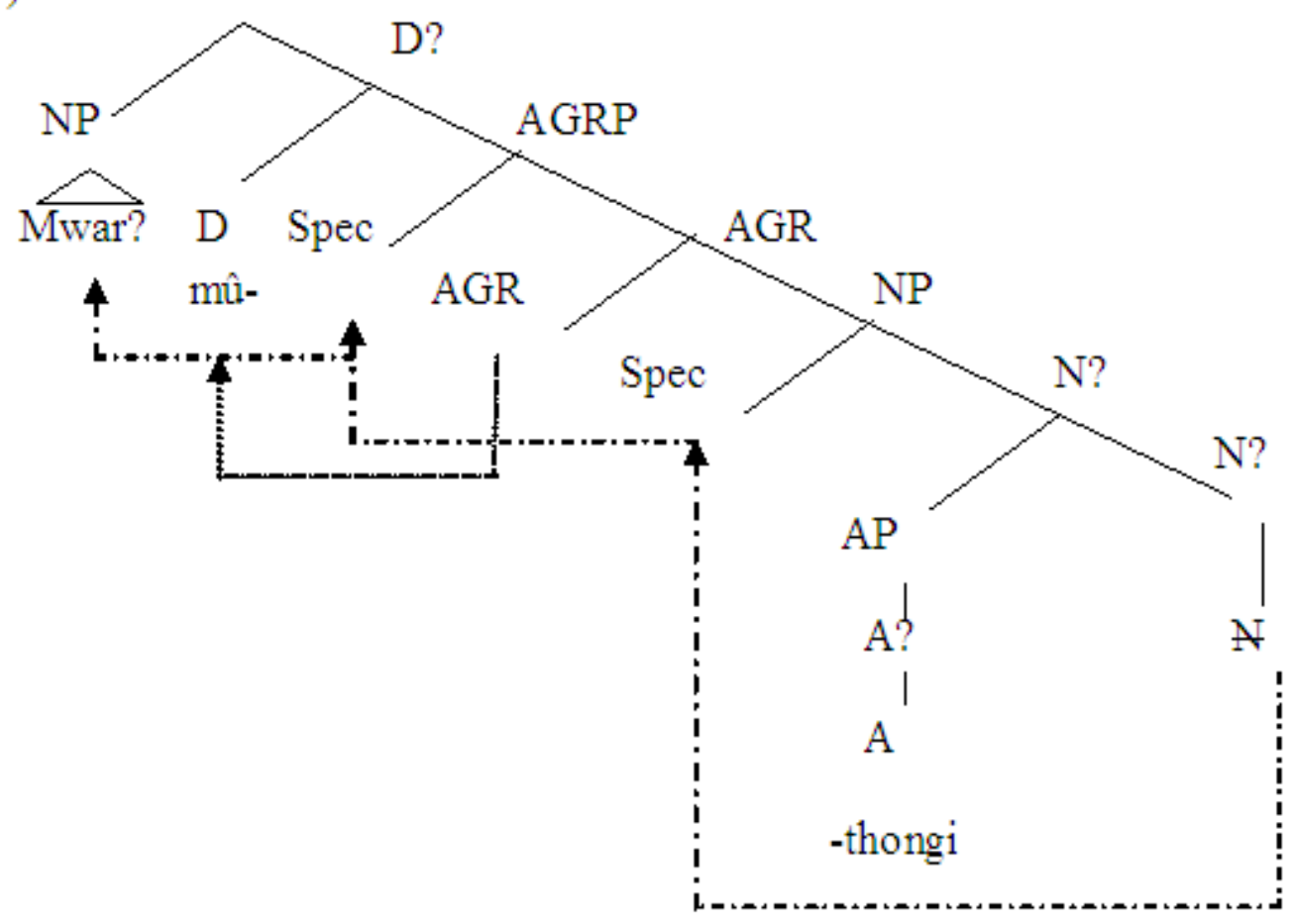

In Structure 14(b), the adjective thongi is base generated as an adjunct to NP Mwarî. The NP then moves through the specifier positions checking agreement features and lands at the specifier position of DP as usual. The agreement marker $m \hat{u}$, being a head moves to occupy the vacant $\mathrm{D}$ position. It is possible to have a string of several such adjectives adjoined to the NP. In such a case, Cinque (1993) suggests that they be projected in a hierarchical order corresponding to quality, size, shape and nationality.

Let us consider the example in 15 :

a) Mw-arî û-mû-thongi, û-mû-raja, û-mû-tuune, mû-Uganda
1-Girl
f-1-beautiful
f-1-tall
f-1-chocolate
1-Ugandan

'A beautiful, tall, big, chocolate Ugandan girl' 


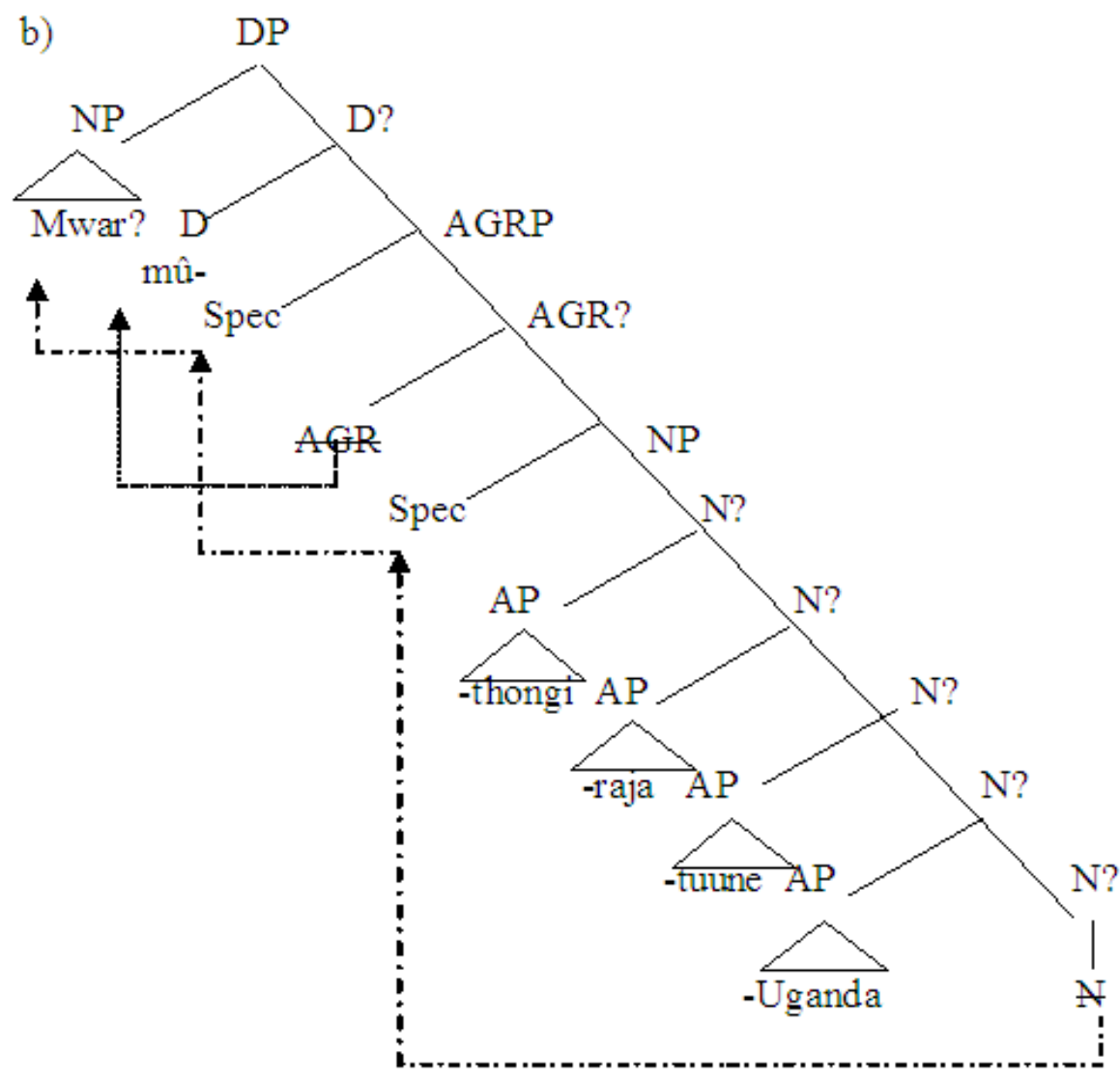

In Structure 15(b), a string of adjectival adjuncts have been projected. The various movements exist as explained in Structure 14(b).

Earlier in the introduction, we noted that Kîtharaka has to forms of expressing association. We have already looked at one of them; the ordinal association. The other form of association expresses possessive relationship between the referent NPs. We termed it the possessive association. If present in the structure, the possessive association follows the adjective, achieving the order; $N>D E M>P O S S>Q U A>O R D . A S S>A D J>P O S S . A S S$. Let us study the following example:

\begin{tabular}{llrrrrrr}
\multicolumn{2}{c}{ a) M-bûri } & i-ira & ci-akwa & ci-îrî & ci-a & mbere & n-tuune \\
9-Goats & 9-those & 9-mine & 9-two & 9-of & first & 9-red & \\
ci-a & Borona & & & & & & \\
9-of & Boran & & & & & &
\end{tabular}

'Those first two red Boran goats of mine'

b) A-ntû ba-ara ba-onthe ba Kîrukuma

2-people 2-those 2-all 2-of Kîrukuma

'All those people of Kîrukuma.'

c) A-ntû ba-ara ba-kwa ba-onthe ba-mûthia ba-kubî ba Ntugî

2-people 2-those 2-mine 2-all 2-last 2-short 2-of Ntugî

'All those last short Ntugî people'

d) A-ntû ba-ara ba-kwa ba mbere ba-îrî ba-onthe be-ega

2-people 2-those 2-mine 2-first 2-two 2-all 2-good

Kuuma Tunyai

from Tunyai

'All those first two good people of mine from Tunyai.' 
All the above are possible structures with the associative construction. Associative construction marking possession can form a string of infinite adjuncts especially when representing family lineage. This scenario is exemplified as follows:

$$
\text { Gaceri wa Njûe wa Njerû wa Ngaramû wa Kamunti wa kîthûmba... }
$$

Gaceri of Njûe of Njerû of Ngaramû of Kamunti of Kithûmba...

'Gaceri daughter to Njûe who is son to Njerû, son to Ngaramû...'

When the relative clause is introduced, it takes the position between the possessive association and the interrogative, when the former and the latter are present. Indeed, all other elements precede the relative clause apart from the interrogative. The resultant order, therefore, is $N>D E M>P O S S>$ $Q U A>O R D . A S S>A D J>P O S S . A S S>R E L . C L A U S E>I N T E R$. This s exemplified as follows:

\begin{tabular}{|c|c|c|c|c|c|c|c|}
\hline & $A-n t \hat{u}$ & $b a-a$ & & $b a-k w a$ & $b a-\hat{i} r \hat{\imath}$ & $b-a$ & mbere \\
\hline 2-people & 2-thos & & 2-mine & 2-two & 2-of & first & 2-all \\
\hline ega & kuuma & Tunyai & $b a-r a$ & $b a$ & & $w a-k w a$ & \\
\hline rood & from & Tunyai & 2-who & & now & 3 -mine & \\
\hline
\end{tabular}

'All those first two good people of mine from Tunyai who know my home.'

\begin{tabular}{|c|c|c|c|c|c|c|}
\hline b) $M-b \hat{u} r i$ & $i$-ira & $c i-a k w a$ & $c i-\hat{-i} r \hat{\imath}$ & $c i-a$ & mbere & n-tuune \\
\hline 9-goat & 9-those & 9-those & 9-mine & 9-of & first & 9-red \\
\hline$c i-a$ & Borona & $i-r a$ & $c i-a-g \hat{u} r^{-}$ & $i r-\quad w-$ & & i- rîkû? \\
\hline 9-of & Boran & 9-that & 9-Pr-buy-Per & M-cAU-fv & & 9-which? \\
\hline
\end{tabular}

'Which first two red Boran goats of mine that were bought?'

Example 18(a) illustrates the position of the relative clause without the interrogative, while (b) shows the relative clause occupying the position between the interrogative and the possessive association. If the DP is formed of only the noun and the relative clause, the latter takes the position immediately after the noun. Let us study Structure 19:

a) A-ntû

ba-ara ba-iyî wa-kwa
2-People
2-who
2-know
3-mine

'The people who know my home.'
b) A-ntû *(ba-ara) bara ba-iyî wa-kwa
2-People 2-those 2-who 2-know 3-mine

'Those people who know my home.'

$\begin{array}{llllll}\text { c) A-ntû } & \text { ba-ara } & \text { ba-akwa } & \text { ba-ra } & \text { ba-iyî } & \text { wa-kwa } \\ \text { 2-People } & \text { 2-those } & \text { 2-mine } & \text { 2-who } & \text { 2-know } & \text { 3-mine }\end{array}$

'Those people of mine who know my home.'

The structures in examples 18 show positions of the relative clause in the context of other elements. There is, notably, something peculiar in structure (b). The presence of the demonstrative in between the noun and the relative clause seem to cause ungrammaticality. However, when the possessive baakwa is placed in between the demonstrative and the relative clause, as in (c) the resultant structure is grammatical. We can, therefore, conclude that positioning the relative clause immediately after the demonstrative in Kîitharaka is untenable.

\section{A ClOSE LOOK AT OTHER BANTU LANGUAGES}

\subsection{Multiple Modification and N-Raising in Kikamba}

Mbuvi (2005) investigates the syntax of Kikamba noun modification and observes the language allows co-occurrence of determiners through creation of specifier positions within the DP matrix, as proposed by Abney (1987). This gives room for demonstratives, possessives and quantifiers to coexist within the same DP structure. To achieve the correct word order in the language, $\mathrm{N}$ moves 
through head positions of agreement phrases within the DP and settles at D. The two cases are illustrated in structure 20:

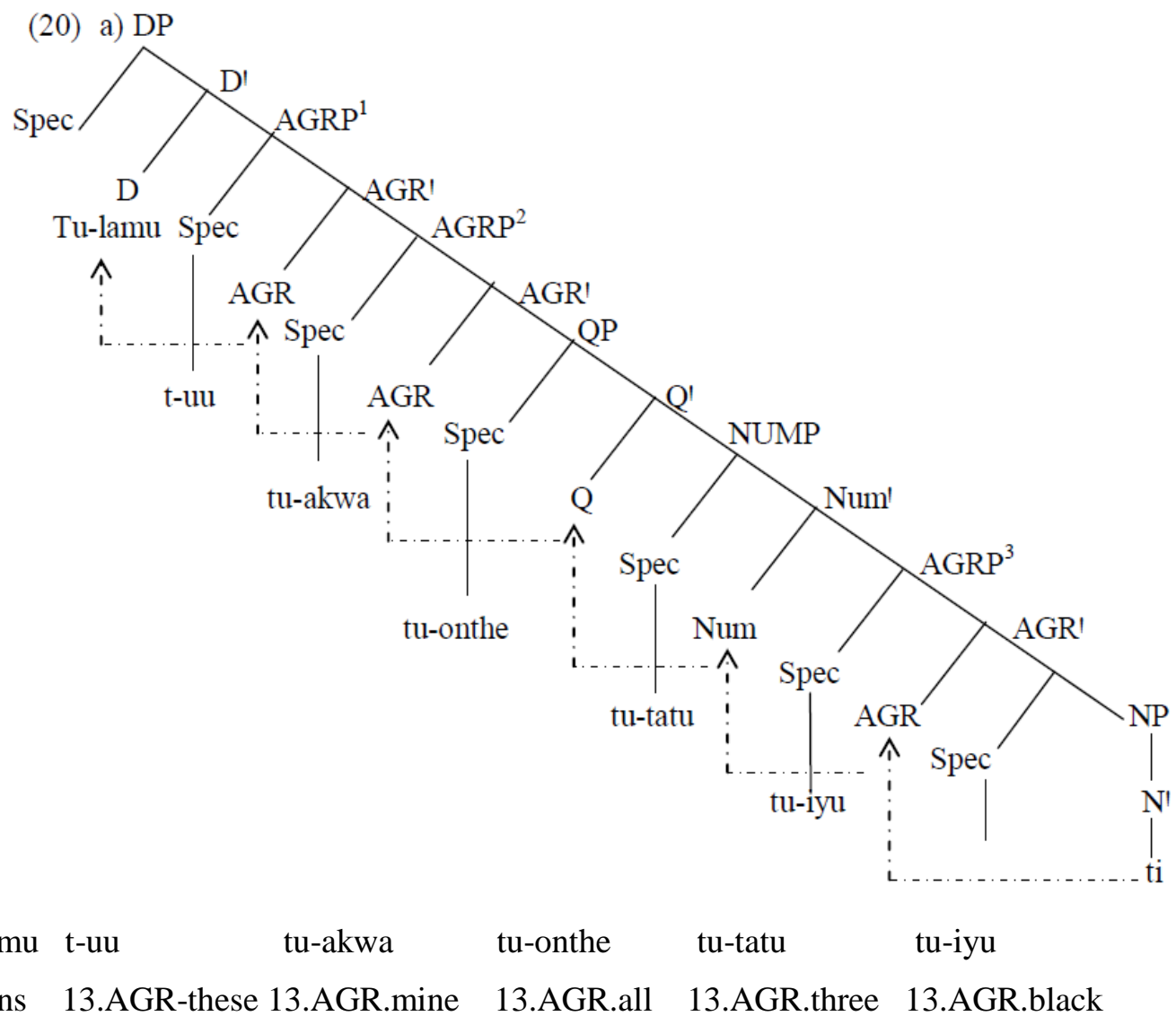

$\begin{array}{clclcl}\text { b) Tu-lamu } & \text { t-uu } & \text { tu-akwa } & \text { tu-onthe } & \text { tu-tatu } & \text { tu-iyu } \\ \text { 13-pens } & \text { 13.AGR-these 13.AGR.mine } & \text { 13.AGR.all } & \text { 13.AGR.three } & \text { 13.AGR.black }\end{array}$

'All these three black pens of mine' (Mbuvi, 2005: p88)

\subsection{Flexible Ordering in Kikuyu, Ekegusii and Mashami}

Just like in Kîntharaka, the D position in Kikuyu can be occupied by the determiner, the possessive or the quantifier. ${ }^{8}$ Similarly, Kikuyu allows a flexible order of modifiers. Any of the three determiners follow the noun depending on how closely it can be associated with the noun (Njagi, 1997). In Ekegusii, it is possible for the three determiners to post-modify the noun. In this scenario, they occur in the order; demonstrative, possessive, quantifier (Mose, 2012). Just like in Kîtharaka, Ekegusii noun modification is typically post-nominal. The only instance that the DP allows pre-modification of the noun is in case of a distributive determiner (inform of a quantifier). A similar case is observed in Mashami, a dialect of a west-Kilimanjaro language spoken in Tanzania. The demonstrative and the possessive occur immediately after the noun and no other modifier can intervene between the two determiners (Rugemalira, 2012)

\subsection{Cross-linguistic Variation in Determiner Positions}

We stated earlier in the introduction, that existing literature on order of modifiers show there is room for departure from the basic ordering associated with Bantu languages. There is evidence of determiner taking different positions across the Bantu languages (cf.Luselelo,2009). In Ngoni (N12), the demonstrative comes last in the string of other elements after the possessive, adjective and quantifier respectively. In Swahili, the demonstrative comes after the possessive and the adjective respectively, while in Basaa (A43), the possessive can appear in two optional positions: pre-nominal or post-nominal, but immediately after the noun. Interestingly, Lusekelo (2009) citing Mous (2003) shows that Nen (A44), a language spoken in Cameroon has only the adjective and a connective relative, as its modifiers of the noun. This shows a sharp deviation from other Bantu languages. The orders with varying positions of determiners are presented in the table that follows:

\footnotetext{
${ }^{8}$ Although it is not specified in what circumstances the three determiners would occupy the D position, we assume that as in Kîtharaka, the determiner that receives focus heads the phrase.
} 


\begin{tabular}{|l|l|l|}
\hline \multicolumn{1}{|c|}{ Language } & \multicolumn{1}{c|}{ Order of elements } & \multicolumn{1}{c|}{ Citation } \\
\hline Kagulu (G12) & N + Poss + Dem + Num + Adj/Ass & (Petzell, 2008) \\
\hline Matengo (N13) & N + Poss/Dem + Other Constituents + Rel & (Ndomba, 2006) \\
\hline Mbugwe (F34) & (Dem) + N + (Dem) + Other Constituents & (Mous, 2004) \\
\hline Ngoni (N12) & N + Poss + A + Quant + Dem & Ngonyani, 2003) \\
\hline Nyambo (E12) & N + Poss/Dem + Other Constituents + Rel & (Rugemalira, 2005) \\
\hline Swahili (G42) & $\mathbf{N}+$ Poss + A + Dem + Num & (Krifka, 1985) \\
\hline Swahili (G42) & (Dem) + N + Poss + (Dem) + (Num) + A + (Num) & (Polomé, 1967) \\
\hline Basaa (A43) & (Poss/Dem)+N +(Poss/Dem)+Other Const.+(Dem) & (Hyman 2003) \\
\hline Nen (A44) & $\mathbf{N}+$ A + Connective Rel & (Mous 2003) \\
\hline
\end{tabular}

Note. Sample ordering of modifiers in selected Bantu language as adapted from Lusekelo (2009) in Nordic Journal of African Studies 18(4): 305-331 (2009). Presentation in a table is ours and some items in the original list have been left out.

\section{SUMMARY}

This paper argues that the order of modifiers in Kîtharaka corresponds to the general order of modifiers in other languages like English, but with parametric variations, resulting from the fact that Kîttharaka exhibits post-nominal modification. Through the principle of movement, however, Kî̀tharaka sets its order of modifiers from the underlying structure.

Additionally, Kîtharaka has a neutral order of modifiers, realized as $N>D E M>P O S S>Q U A>$ $O R D . A S S>A D J>P O S S . A S S>R E L . C L A U S E>I N T E R$. Any change from this order may be attributed to the fact that some modifiers may be given focus, appearing before those in the neutral order, to achieve emphasis.

\section{REFERENCES}

[1] Abney, S. (1987). The English noun phrase in its sentencial aspect ( $\mathrm{PhD}$ dissertation). Massachusetts Institute of Technology, Massachusetts: MIT Press.

[2] Ashton, E. O. (1944). Swahili grammar(including tone). London: Longman's Green And Co. Ltd.

[3] Bernstein, J.B. (1993) Topics in the syntax of nominal structure across Romance (Doctoral dissertation). The City University of New york, New York.

[4] Cinque, G. (1990). Agreement and head- to- head movement in Romance NPs. A paper presented at XX Linguistic Symposium on Romance Languages. Ottawa

[5] Cinque, G. (1993). On the evidence of partial N-movement in the Romance DP. MS, University of Venice.

[6] Cinque, G. (2005). Deriving greenberg's universal 20 and its exceptions. Linguistic Inquiry, 3, 315--332.

[7] Coene M. \& D'Hulst Y. (2002). From NP to DP: The Syntax and Semantics of Noun Phrases. Amsterdam: John Benjamins.

[8] Crisma, P. (1990). Functional categories inside the Noun Phrase: A study on the distribution of Nominal Modifiers. University of Venice.

[9] Crisma, P. (1993). On the adjective placement in Romance and Germanic event nominals. Rivista di Grammatica, 61-100.

[10] Giusti, G. (1997). The categorical status of determiners in L. Haegman (Eds.) The new comparative syntax (pp. 95-123), London and New York: Longman.

[11] Guthrie, M. (1967). Comparative Bantu: an introduction to comparative linguistics and the pre-history of the Bantu languages. Farnborough: Gregg Press.

[12] Lusekelo, A. (2009). The structure of the Nyakyusa noun phrase. Nordic Journal of African Studies, 4(18), 305-311.

[13] Mchombo, S. (2004). The syntax of Chichewa. Cambridge: Cambridge University Press.

[14] Mohamed, A. (2001). Modern Swahili grammar. Nairobi: EAEP.

[15] Mose, E. (2012). The structure and role of the determiner phrase in Ekegusii: A minimalist approach (Unpublished masters dissertation).Kenyatta University, Nairobi.

[16] Ngonyani, D. (2003). A grammar of Chingoni. Muenchen: Lincom Europa.

[17] Nurse, D \& Philipson, G.(2003). Introduction. In G. Philipson. D. Nurse, The Bantu Languages (pp. 112). London: Routledge.

[18] Radford, A. (2004). Minimalist syntax:exploring the structure of English. New York: Cambridge University Press. 
[19] Rizzi, L. (1990). Revised minimality. Cambridge: MIT Press.

[20] Rugemalira, J. (2007). The structure of the Bantu noun phrase. Working Papers in Linguistics, 15, 135148.

[21] Sulemana. (2012). The structure of the determiner phrase in Buli (Unpublished MA dissertation). University of Ghana, Legon.

[22] Shlonsky, U. (1991). Quantifiers as functional heads: A study of quantifier float in Hebrew. Lingua .

[23] Velde Van de, M. (2005). The order of noun and demonstrative in Bantu. In J. M. K. Bostoen, Studies in African Comparative Linguistics (pp. 421-441). Tervuren: Royal Museum for Central Africa.

[24] Zerbian, S \& Krifka, M. (2008). Quantification across Bantu languages. (L. Mathewson, Ed.) Quantification: A cross-linguistic perspective, North Holland Linguistic Variations, 64, pp. 383-414.

\section{AUTHOR'S BIOGRAPHY}

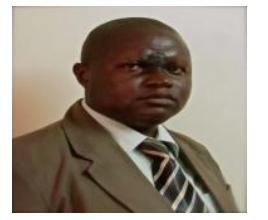

Prof. Peter Kinyua Muriungi, is a Professor at Tharaka University College. His research interests are in the area of language universals, the syntax of focus, questions, Bantu verbal morphology and generally Bantu syntax.

Mr. Patrick Njue Kanampiu is a part time lecturer at Tharaka University College. His main interest is the syntax of Bantu, particularly the Bantu Noun Phrase.

Citation: Patrick Njue Kanampiu, Peter Kinyua Muriungi. Order of Modifiers in Kîtharaka Determiner Phrase "International Journal on Studies in English Language and Literature (IJSELL), vol 7, no. 6, 2019, pp. 10-21. doi: http://dx.doi.org/10.20431/2347-3134.0706002.

Copyright: (C) 2019 Authors. This is an open-access article distributed under the terms of the Creative Commons Attribution License, which permits unrestricted use, distribution, and reproduction in any medium, provided the original author and source are credited. 